\title{
Barbarians in/of the Land: Representations of Muslim Youth in the Canadian Press
}

\author{
Yasmin Jiwani \\ Professor \\ Communication Studies Dept. \\ Concordia University ${ }^{1}$ \\ yasmin.jiwani@gmail.com \\ With \\ Matthew Dessner \\ Research Assistant \\ Communication Studies Dept. \\ Concordia University \\ matthewdessner@gmail.com
}

\begin{abstract}
This paper examines representations of Muslim youth in a major Canadian newspaper, The Globe and Mail, over a four-year period (2010 to 2013). The first part of the article reviews some of the relevant literature regarding Muslim representations in the Western, mainstream media, paying particular attention to representations of Muslim youth. Based on a close analysis of a corpus of 158 news stories, a qualitative and quantitative analysis of the coverage is presented. Using a postcolonial and critical race perspective, this article traces the ways in which Muslim youth are represented, illustrating the ways in which a racial logic inscribes them. The findings suggest that Muslim youth are cast not only as an enemy within the nation state, but also as a contaminating force that must be disciplined or ejected from the body politic. They are, in short, barbarians in and of the land. At the same time, these representations cohere to produce an image of the nation as benevolent and dedicated to universal standards of truth and justice.

And the barbarian's relationship with that speck of civilization... is one of hostility and permanent warfare. The barbarian cannot exist without the civilization he is trying to destroy and appropriate...He does not make his entrance into history by founding a society, but by penetrating a civilization, setting it ablaze and respectively destroying it. (Foucault, 2003, p. 195)
\end{abstract}

\section{Introduction}

Since the time of Edward Said's $(1978 ; 1981)$ groundbreaking work documenting Orientalism, there is now a wealth of literature that details Western media stereotypes of Muslims and Islam (e.g. Karim, 2000; Mamdani, 2004; Muscati, 2002; Razack, 2008; Steuter \& Wills, 2009). Maira (2009, p. 29) cynically refers to this as the bourgeoning "post 9/11 area studies". Ushered in by the tragic bombings of $9 / 11$, these "area studies" have embraced both a progressive, critical

\footnotetext{
${ }^{1}$ This research was made possible by funding from the Canadian Institute for Health Research (CIHR). Journal of Contemporary Issues in Education, 2016, 11(1), pp.36-53. 
examination of the US imperial formation and the regressive practice of identifying and surveilling scholars working on issues related to Islam and Muslims in Western academies. On the progressive front, scholars have focused on the stereotypical media narratives and representations that make Muslim bodies legible in particular national and social contexts (e.g. Baird, 2009; Hage, 1998; Magnet, 2012; Smolash, 2009), and subject to heightened surveillance as well as criminalization.

Within the news media, the coverage has been equally stereotypical. For instance, Richardson (2004) has extensively documented the ways in which the British broadsheets represent Islam and Muslims in a pejorative manner. Similarly, studies of the Canadian and American mainstream press and popular media have also identified the stereotypically negative representations of Muslims and Islam (e.g. Byng, 2010; Boggs \& Pollard, 2006; Hirji, 2011; Jiwani, 2004; 2010; Morey \& Yaqin, 2011; Odartey-Wellington, 2009; 2011; Shaheen, 2001).

These stereotypes function as floating signifiers, ready to be harnessed to the dominant discourse of the day. For example, whereas Muslim women were historically thought to be licentious and provocative, they are now stereotyped as sexually oppressed by an ultra-patriarchal and repressive Islam (Richardson, 2004). Stereotypes are also fixed, leaving a rigid trace or palimpsest of the real (Morey \& Yaqin, 2011). In the news media, such stereotypes work as discursive devices, offering ready-made templates (Kitzinger, 2000), to comprehend an event. Framed within a particular subset of occurrences, the stereotype gains its potency as an explanatory vehicle wherein the frame itself provides the necessary cues to prime particular interpretations. However, stereotypes while essentially presenting one-dimensional features are also inherently ambivalent (Hall, 2007). For every negative portrayal, there is a positive dimension that the stereotype gestures towards, such as the "good Muslim" / "bad Muslim" dichotomy (Mamdani, 2004). This is what makes the stereotype amenable to conscription by a dominant discourse. As with all discursive elements, there is a gendered dimension to stereotypes and in the case of Muslims, it is, as Razack (2008) aptly points out, the imperilled Muslim woman against the white knight who rescues her, or the lustful, dangerous Muslim man (Bhattacharyya, 2008), who seeks to subjugate her (see also Jiwani, 2009). The rescue motif, as Abu-Lughod (2002) and others have pointed out, is an embedded feature of colonial discourse used to buttress colonial and imperial agendas.

\section{Muslim Youth}

Representations of Muslim youth are similarly textured by the larger discourses operative in the contemporary landscape. Framed within the dominant discourse of the "War on Terror", many of these representations focus on young Muslim men as potential, if not actual, terrorists (Maira, 2009), and young Muslim women as caught within a cultural clash signified by their struggles against an oppressive Islam as embodied in the ultra-patriarchal practices of their fathers and brothers (Sensoy \& Marshall, 2010; Zine, 2002; 2009). Indeed, these representations fail to account for the history or social location of Muslim youth - one that is marked by underemployment, discrimination and targeting (Helly, 2004; Haque, 2010; Khalema \& WannasJones, 2003). Yet, to date, few studies have documented the precise manner in which the mainstream Canadian news media depict Muslim youth.

Journal of Contemporary Issues in Education, 2016, 11(1), pp. 36-53.

ISSN 1718-4770 (C) 2016 University of Alberta/Centre for Global Citizenship Education and Research

http://ejournals.library.ualberta.ca/index.php/JCIE 
In their analysis of the news coverage regarding the "Toronto 18" case and the arrest of eighteen Muslim youth on the grounds of their complicity in planning and executing terror plots, Miller and Sack (2010) argue that the majority of the coverage utilized a "home-grown terrorism frame". This frame effectively assembles the tropes associated with Islam and terrorism (Karim, 2000), and sutures them to issues of state security. In other words, the securitization of the state is made possible by a discourse of terrorism which pivots on play of orchestrated stereotypes young Muslim men driven by a sense of grievance, unable to 'fit in', and incapable of performing as docile citizens. They are "Generation Jihad: Angry, Young, Born-Again Believers" according to a headline from The Globe and Mail quoted by Miller and Sack. Yet, the template used in the coverage of "Toronto 18" was etched before - in the mainstream media's coverage of "Operation Thread" (Odartey-Wellington, 2009) that involved the arrest of 23 young Muslim men, most of them marked by the first name Mohammed - many of whom were subsequently deported. They were arrested for participating in a terror cell, a network whose existence was tenuous at best. The coverage, as Odartey-Wellington points out, generated a moral panic in which "young Arabs and ethnic minority Muslims serve as the objects by which the threat can be mediated, recognized by the public, surveilled and controlled by the relevant state apparatuses" (p. 36). As Stenvall (2003) notes,

The elements of threat inherent in the terrorist network metaphor largely depend on the secrecy and unpredictability of these networks. Terrorist networks are presented as "clandestine" and "shadowy"; and since they are "multinational", it is implied that no one in the world can feel safe. Accordingly, it can be argued that the sense of the word terrorist in public discourse really has changed, in that the word today evokes even stronger - and more persistent - negative emotions (such as fear and terror) than it did before September 11, 2001. (p. 397)

So strong is the terror stigma attached to the male Muslim body, that it has followed even that of Omar Khadr, a child soldier who was apprehended in Afghanistan and subsequently jailed in US prison in Guantanamo Bay for eight years before being transferred to a Canadian prison for another eight year term (Jiwani, 2011). We shall come back to the Khadr case as it was a notable thread running through our corpus of news coverage. What is important to note is that race and religion, as Bahdi (2003) astutely observes, have become the proxy for risk. Young Muslim men are the embodiment of risk; a risk made more evident in Canada's refusal to accept them as part of its intake of Syrian refugees (The Guardian, 2015).

Nonetheless, there is another side to this stereotype, and this deals with Muslim youth attempting to "fit in". The performative aspects of citizenship have been emphasized in the literature dealing with the negotiation of Muslim identity in diasporic communities in the West (e.g. Harris \& Roose, 2014; Kassam, 2011; Maira, 2009). At the same time, the influence of consumer culture as a passport to "fitting in" has also been noted (Jiwani, 2014). However, "fitting in" also constitutes the sign of the "good Muslim", one who can set aside the lived aspect of Islam and privatize it, much as religion is privatized in a secular society - present but absent from the public gaze. As Mamdani (2004) observes, "good Muslims are modern, secular, and Westernized, but bad Muslims are doctrinal, anti-modern, and virulent" (p. 24). How then are these stereotypes prevalent in contemporary press reporting of Muslim youth? In the sections that follow, we discuss some of the findings from our corpus of news articles from The Globe Journal of Contemporary Issues in Education, 2016, 11(1), pp. 36-53. 
and Mail.

\section{Methodology}

A census (Sampert, 2006) of articles concerning stories of youth in The Globe and Mail was conducted using the Factiva database. The search terms utilized included the following: youth, young people, teen, teens, teenage, teenaged, teenager, teenagers. Excluding stories in the Arts/Entertainment, Sports, Fashion, Globe Drive, Report on Business Snapshot, Report on Business Financial Profile, Home Cents, Number Cruncher (Stock Column) Sections, and international stories, the search yielded 2,337 news accounts in total. Of these, 158 were stories that either specifically focused on Muslim youth or significantly referenced them in passing. In the sections that follow, we focus on these 158 stories.

In parsing through the articles, we categorized them using the following descriptors:

Radicalization \& Terror for stories that discussed Muslim youth involved in terrorist activities or as having been radicalized; Surveillance for stories concerning state surveillance of Muslim youth; Immigration for those which commented on immigration issues involving Muslim youth; and, Honour Killings to reference and categorize Muslim victims of honour crimes. In addition, due to the high number of stories referencing Somali youth, we coded these stories separately within the larger category of Muslim youth. Gang violence, which was a common theme in the stories dealing with Somali youth was also coded separately, as well as in the Somali youth category where the reference was explicit. Additionally, stories that featured "positive" representations of Muslim youth were coded, as were stories where these representations were either mentioned in passing or were not the main aspect of the coverage. Those stories where Muslim youth were alluded to, or where there was an assumed connection, were demarcated as "floating or unsaid". In some cases, these included stories about individuals who had previously been identified as Muslim or terrorists. Not all of our categories were mutually exclusive and so we relied on the most dominant motif in an individual story to determine in which category it would best fit. While our corpus is not exhaustive and is contingent on the usual problems associated with database searches, it does provide insights that can help to map out the terrain of the mediascape concerning Muslim youth.

The diagram below offers a pictorial representation of stories in each of the categories. The red portions represent those stories featuring Somali youth. The blue signifies all other representations of Muslim youth.

Journal of Contemporary Issues in Education, 2016, 11(1), pp. 36-53. 


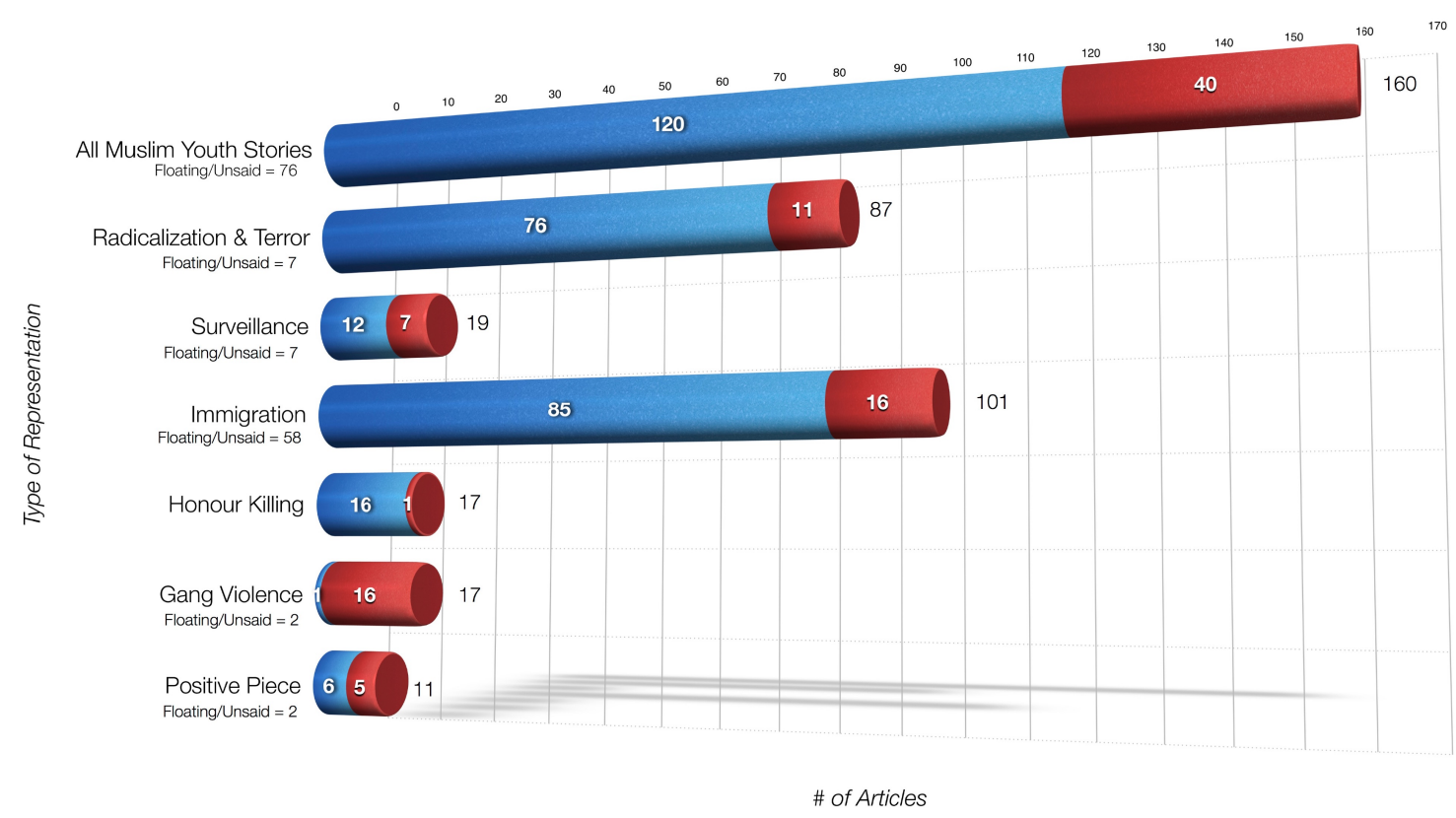

Figure 1: Muslim Youth Representation in The Globe and Mail (2010-2013)

Table 1: Quantitative Profile of the Coverage

\begin{tabular}{|l|l|l|}
\hline Year & Number of Stories & Number of Muslim Youth Stories \\
\hline $\mathbf{2 0 1 0}$ & 537 & 51 \\
\hline $\mathbf{2 0 1 1}$ & 627 & 15 \\
\hline $\mathbf{2 0 1 2}$ & 598 & 38 \\
\hline $\mathbf{2 0 1 3}$ & 575 & 54 \\
\hline TOTAL & 2337 & 158 \\
\hline
\end{tabular}

While articles on immigration were the highest in number, many of these were categorized as "floating" or where Muslim youth were mentioned in passing. In contrast, articles dealing with radicalization and terror were more likely to deal directly with Muslim youth. Tracking the themes over the four years reveals the following chronology: security concerns, terrorism, the

Journal of Contemporary Issues in Education, 2016, 11(1), pp. 36-53. 
"new" profile of young "jihadists", gang-related murders, drug crimes and murder, and honour killings. Within this chronology, several issues dominated the coverage: the repatriation of Omar Khadr from Guantanamo, the murders of Somali youths, the court trials of the "Toronto 18", and the fatal shooting of Sammy Yatim, a Syrian youth by the Toronto Police. We turn now to a discursive analysis of the coverage.

\section{Terrified/Terrifying Nation}

The eviction of groups of people from political community begins with their difference, coded as an incomplete modernity that poses a threat to the nation. While nationalism has always demanded the stigmatization of the foreigner, increasingly that stigmatization carries with it the probability that the stigmatized group will be literally expelled (deported), marked permanently as undeserving of the full benefits of citizenship, or abandoned. (Razack, 2008, p. 84)

As Razack remarks above, the differentiation of an "us" from "them" is a key discursive move by which targeted groups are alienated. In his insightful analysis of elite discourse and racism, Teun van Dijk (1993) identifies an "ideological square" as a primary discursive move by which the press makes and marks a difference between "us" and "them". Whereas, "we/us" are positively valued and valorized, "they" or "them" are negatively valued. In this way, the media projects all that is undesirable and contra hegemonic on to "them". "They" in turn become the threats that have to be expelled from the body politic, or isolated and marginalized. "Their" concerns become trivialized if not dismissed outright. But how is it possible to define an Other when "they" look and act like "us"? What "somatechnologies" (Pugliese, 2009) - technologies of the body, on the body and associated with the body - can one use to identify the difference that Razack (2008) speaks to? This is where Pugliese's concept of compulsory visibility comes into play; for the Muslim body is rendered, in the news media most especially, highly visible.

\section{Homegrown Terror}

The majority of news accounts focused on homegrown terrorism, stemming in part from the media's coverage of the trial of the "Toronto 18 ". The coverage in general stressed the emergence of a new generation of "jihadists"- a euphemism of terrorism linked to Islam. These "new" terrorists were the cause of considerable concern. For example, in describing the lead figure in the "Toronto 18" group, one news account portrays him as follows:

An educated and affluent thirty something entrepreneur - born in the Middle East but raised in Canada - who allegedly saw an opportunity to profit from the chaos he would cause....A decade older, better educated and far better off than most his co-conspirators, Mr. Abdelhaleem doesn't fit the profile of the teenagers and twenty somethings convicted to date. (Freeze, 2010)

In a column concerning the apprehension of another terrorist suspect, Khurram Sher, columnist Margaret Wente pens the following:

He doesn't fit our mental picture of a would-be terrorist. He's not a disaffected kid who fell in with the wrong crowd. He is not a hate-filled product of poverty and disadvantage. He's not even a second-class citizen, such as France's French-born

Journal of Contemporary Issues in Education, 2016, 11(1), pp. 36-53. 
Muslims who speak with perfect Parisian accents but will never break into the elites. Instead, Dr. Sher's the product of Canada's uniquely successful multicultural meritocracy - a homegrown, ball-hockey-playing, fun-loving fellow who zipped through one of the toughest med schools in the country and made fun of religious Muslims on Canadian Idol (Wente, 2010).

Here, Wente alludes to the fear that the terrorist could be the person next door. In other words, "they" can look like "us" and act like "us" and therefore, we need to be on guard. The enemy is within, and can easily constitute a fifth column. News articles, as Miller and Sack (2010) contend, have a significant impact on audiences, particularly those who consider the columnist favourably, and Wente, it must be noted, has a considerable following.

However, while columnists can sway the public, the news media's reliance on official sources, such as government and security sources (e.g. the police) also command considerable legitimacy. Hence, an article that quotes credible sources such as reports by experts and specialized government agencies such as the Canadian Security and Intelligence Service (CSIS) is likely to not only draw more attention, but also elicit acquiescence on the part of the audience because of the inherent and assumed facticity of the information provided. Here, for example, is one such account of CSIS's report on radicalization titled "Canadian extremists likely homegrown: 'Secret' CSIS Report":

....none of the radicals studied by CSIS were "assessed to be poorly integrated into Canadian society." And these radicals tend to be relatively young and wellintegrated members of society... "That data appears to match what has been claimed in the literature: i.e. that radicalization and terrorism is largely a young person's game" (18-35), the study says. (Freeze, 2013)

Headlines, van Dijk (1993) contends, act as "cognitive organizers" - they tell us what to expect and summarize the story for us, from the viewpoint of those writing it. Here, what is interesting to note is that the implied notion assumes these young people don't really have any legitimate grievances. In other words, their involvement with terrorism is simply a "game". Further, that "game" is a lucrative one, not only for the profits it brings in terms of the presumed privileges of martyrdom, but also "because even nobodies can aspire to be somebodies. And a nobody who feels persecuted by society (petty criminals often have a victim complex) can be tempted to vent that hostility in murderous ways" (Wente, 2013).

The news accounts suggest that the turn to radicalism is illogical, indicating that those who are radicalized were normal at one time and then suddenly became abnormal. This is apparent in the following account concerning one of three friends, who presumably left Canada, to fight alongside terrorist groups.

In 2008, Aaron Yoon, the London, Ont., man who has been reported to be in an

African jail under mysterious circumstances, was a "fun-loving" teenager who worked part-time at a local restaurant and hung out with friends from work. But according to a former co-worker, something changed in the Korean-Canadian teen over the next few years. She watched her former friend become increasingly isolated and religious. "My Facebook was flooded with posts about Islam... It was getting excessive so I just deleted him," the young woman...said. (Hui, Freeze, \& Thanh Ha, 2013)

Journal of Contemporary Issues in Education, 2016, 11(1), pp.36-53. 
This theme is reiterated in various other accounts leading readers to surmise that radicalization is this amorphous process that emanates from a phenomenon called "Islam", and is relayed by the Internet. It is as if exposure to Islam results in an alchemical reaction, drastically altering the individual's personality. One outcome of this is the legitimization of surveillance. The news accounts report on state authorities and police asking the communities to participate in this surveillance, and further, commending them for doing so and behaving like "good Muslims" (e.g. Chase \& White, 2010).

A key thread linking homegrown terrorism to Muslim youth is the issue of immigration and crime. Numerous stories referenced the out-migration of Muslim youth as mentioned above. However, there were other accounts that referred to the deportation of youth who had been categorized as terrorists by the state, even though they had grown up in Canada (Wingrove, 2012). Immigration status then enhances the suspect nature of those who will not "fit", making them likely to be deported, and thereby exorcised from the body politic. On the other hand, if the nation can eject those it deems undesirable on the grounds that they do not legally belong, then it also makes itself accountable for citizens, who are also Muslim, imprisoned elsewhere. This is where immigration status becomes a strategic card that can be used to contest the state as occurred in the case of Omar Khadr.

\section{Omar Khadr - An Anomaly?}

A notable theme throughout the four years of coverage was the subject of Omar Khadr, his imprisonment in Guantanamo Bay, his status as a child soldier, the Canadian government's complicity with the US intelligence apparatus, and abandonment of this Canadian citizen. This is quite a departure from earlier accounts of Khadr in the mainstream press (see Jiwani, 2011; Shephard, 2008; Williamson, 2012). Apprehended as a child-soldier, Khadr was one of the only inmates at Guantanamo unclaimed by a Western nation whose citizens were confined there. The coverage that we examined pointed to a positive representation of Khadr, gesturing to and sometimes indicting the Canadian government for abandoning him and refusing his repatriation. A Supreme Court decision subsequently forced the government to bring him back to Canada under the condition that he plead guilty to the charges of terrorism and murder leveled against him. Khadr agreed, and subsequent reportage focused on his return and rehabilitation.

The interesting aspect of the news coverage is the stark contrast between the portrayal of young Muslim men as terrorists incarnate, and Khadr as a victim of government inaction and politics. On the one hand, these positive portrayals, which tended to express a sentiment of benevolence and fairness on the part of Canadians, consistently made mention of the Khadr family's connection with terrorism. Khadr thus becomes an exception marked by his age at the time of his apprehension (a 15 year-old), the conditions under which he was found - which seem to refute his involvement in the murder of an army officer, - and Canada's violation of an international treaty concerning the treatment and rehabilitation of child-soldiers. The reports offer a trenchant critique of the Canadian government. Here is an example of one such account from an editorial:

And what role did Canada play? Shamefully, it sent its officials to bully him

[Omar Khadr] into giving out incriminating information that it then handed to his

prosecutors, an act the Supreme Court of Canada unanimously condemned. The

Journal of Contemporary Issues in Education, 2016, 11(1), pp. 36-53. 
Canadian government then declared, "Let the process work." Some process. (The Globe and Mail, 2010, November 1)

However, the editorial ends with a statement reiterating Khadr's identity as a terrorist but calling on Canadian values of fairness and justice to recognize his status as a youth. Notwithstanding the benevolent stance of many of the editorials covering the Khadr case, the tone of opportunism was an emerging theme once Khadr was repatriated. For instance, there were allusions to how the Canadian justice system was soft and would work in favour of Khadr by enabling his early release (e.g. Makin, 2010).

This transformation in Khadr's representation may be attributed to the concerted grass roots mobilization that occurred as a result of his imprisonment in Guantanamo, and the publicity that advocates managed to garner. That aside, it may also have to do with the more important ideological task at hand - shoring up the national imaginary of Canada as a fair and just nation.

\section{Gangs/Drugs, Murders and Terror: The Somali Connection}

The theme of drug and gang warfare, often culminating in the murder of young Black men, was also a prominent theme in the corpus we examined. The nexus connecting these various issues was the youths' Muslim identities. In these reports, the figure of the Somali youth is the site where race and religion come together to signify a potent and toxic mix of danger, risk, mayhem and savagery. Here we see the Somali body making a journey from the housing projects of Toronto and its outskirts to Fort McMurray in Alberta. The relocation is a quest for stable work and money, but the Somali body ends up on the street, victimized by murder, and tainted by the drug trade. The news accounts make clear that this is a "lost generation":

Mr. Jama is among what some fear is a lost generation of Somali-Canadian young men. About two dozen have been killed in Alberta over the past half-decade, overwhelmingly Canadian-raised and involved in drugs. Somalis call them the ciyaal baraf, or children of the snow. It's a kind of insult - neither truly Somali nor truly Canadian. (Wingrove, 2012)

The quote above suggests that Somali youth are caught in a culture clash - between the traditions of their parents and the modernity of Canada. However, a structural analysis would reveal that for many Somali youth, dead-end jobs, discrimination and the sense of abandonment they experience growing up in Canada, impact their sense of identity and belonging to the nation. As Black and as Muslims, they face the interlocking influences of racism and Islamophobia.

Many of the articles on Somali youth focus on policing strategies such as outreach, collaboration with mosques and community groups, and the hiring of Somali-Canadian police officers. However, what is most interesting is the ambivalence communicated in these accounts. On the one hand, there is a glowing commendation of Somali communities who have alerted the government and police about radicalized youth in the community, and on the other hand, there is a sense of hopelessness about this "lost generation." That hopelessness is also communicated through the use of exemplars of exception, as for instance, a young "Canadian-trained" Somali doctor who was able to transcend the limitations imposed on her by her race, class, and gender (Anderson, 2013), implying that if she can do that, so can the others.

Journal of Contemporary Issues in Education, 2016, 11(1), pp. 36-53. 
The recruitment of Somali youth into terrorist cells abroad was a constant motif in the coverage. In a story ostensibly about the declining numbers of Somali youth going to join al-Shabab, the terrorist network in Africa, readers are reminded that:

...the flow of aspiring fundamentalist fighters from the West to Syria is accelerating as that conflict becomes a global epicentre for self-styled jihadists. "They are going in great numbers," said a former federal official, adding that there has not been a migration like this since Afghanistan in the 1980s. Overall, he said, "you're talking hundreds and hundreds." (Freeze \& Friesen, 2013)

Again, the reliance on numbers and the need to provide context constitute the rationale for the inclusion of this piece of information. However, against a background where the association between Muslim youth and terrorism is so sharply etched in the collective imagination, its inclusion combined with its articulation from an authoritative and hence credible source, reinforces the stigma. More than that, this information feeds into a moral panic (OdarteyWellington, 2011) about Muslim youth as embodiments of homegrown terror, importing and exporting terror at will.

\section{The Case of Sammy Yatim}

On July 27, 2013, Sammy Yatim, an 18-year-old Syrian youth, was shot by Toronto police in the downtown section of the city. At approximately midnight, Yatim was travelling in a streetcar and had apparently told the passengers to leave after having first indecently exposed himself. As the situation continued, everyone but Yatim - who was now wielding a three-inch knife - had vacated the streetcar. According to the news accounts, police arrived and ordered him to "drop the knife" and step out of the vehicle. The incident was video-taped by an eyewitness and soon went viral. Yatim was shot nine times and then tasered and according to the accounts, "crumpled" after the first 3 shots were fired (Mahoney, Andreatta, \& White, 2013). The tragedy sparked widespread protest and calls for police accountability. Thereafter, one of the 22 police officers on the scene, who had fired the shots, was charged with manslaughter.

Yatim was not branded a terrorist. Instead, as the subsequent stories revealed, he was a Christian Arab from Syria. Hence, instead of reverting to the terrorist frame, the coverage of the incident attempted to offer a logical explanation - Yatim as "brandishing a knife" and therefore as threatening to the passengers on the streetcar. When this didn't work because other passengers corroborated that he didn't seem rational and that even when presented with the opportunity to hurt a fellow passenger, he simply told everyone to leave (Blaze Carlson, 2013), the story shifted to Yatim himself. Under the title, "Caught between two worlds; A shy kid who had a fascination with knives; A teenager who grew up between two countries; A son with concerned parents, and a classmate eager to be cool," Blaze Carlson and Vidya Kauri (2013) elaborate on this victim of a culture clash, commenting that it was "his collection of knives that ultimately, albeit indirectly caused Mr. Yatim's demise". In his column on the shooting, Marcus Gee (2013), another popular columnist at the paper, opined: "There is, thankfully, no evidence of racial bias here, or even of simple "police brutality",.

This denial of racial profiling and bias remained a consistent theme in the coverage even when it was found that there had been no need for the use of such excessive force by the police. Instead,

Journal of Contemporary Issues in Education, 2016, 11(1), pp. 36-53. 
the articles that recounted this story pointed to several cases where excessive force was used by the police on mentally challenged individuals. However, one could surmise here that the connection between Middle Eastern "looking" youth and terrorism is so conjoined in the popular imagination that it may perhaps have influenced how the police dealt with Sammy Yatim; their actions propelled by the view of Muslim youth as dangerous and lethal (Dossa, 2008). So, although he wasn't a Muslim, Sammy Yatim looked like a Muslim, much as the Sikh men who were murdered in the immediate aftermath of 9/11 in the US, appeared "like" Muslims (Maira, 2009).

\section{The Reader-Generated Series: "Time to Lead"}

In the first week of July, 2011, The Globe and Mail initiated a series focusing on Islam and youth in Canada. The series began with a story titled "The gap between two solitudes; Young Canadian Muslims say bridging the 'us and them' divide requires breaking down some harmful, outdated stereotypes" (Bascaramurty, 2011). It concluded with the following description: "Time to lead is journalism driven by our readers - the ideas come from you. This week's series focuses on Muslims in Canada, as they find their way between tradition and modernity." As Hall et al. (1978) note, by identifying the situation and thereby imposing the limits of the debate, the news media constrain and curtail information to fit the frame. In this case, the paper's emphasis on defining Islam as "tradition" and Canadian society as "modernity" effectively framed the issue. The articles in the series focused on the culture clash, but also in the third installment, published a selection of the reader response. This response was largely concentrated to giving voice to public anxieties about Islam and Muslims, and in particular, the threat represented by both. The second installment of the series featured a longer comment from a Muslim woman that presented the argument that it was not the parents who were traditional but rather "it's their children - in desperate need for identity - who have turned to conservative, hard-line and politicized Islam for answers". This trend to embrace a politicized Islam has led to bloodshed in many parts of the world and is growing rapidly - and going unchecked - in Canada" (Fatah, 2011). What is apparent here is the voice of the native informant - the "good Muslim" who informs on her community and performs the role of the dutiful citizen. She alerts the public about the dangerous Muslim youth who need to be surveilled and disciplined.

Moreover, the very title of the series, "Time to Lead" presupposes that Muslim youth and communities haven't already been leading the way, begging the question: "To where should they be leading their communities?" The implicit message is that Muslim youth need to be trained (domesticated) to lead their communities and additionally, to demonstrate their capability in ways that are intelligible to the nation. In other words, they need to become more like "us."

\section{Rescuing Young Muslim Women}

If young Muslim men are dangerous and lethal, then young Muslim women are passive and oppressed - imperiled as Razack (2008) puts it. That seems to be the general equation suggested and, even more so, underscored in the coverage of the murders of three young women of the Shafia family. Framed as "honour killings", the news accounts posthumously rescued the young women (see Jiwani, 2014; Olwan, 2013) from the oblivion facing so many women victims of

Journal of Contemporary Issues in Education, 2016, 11(1), pp. 36-53. 
domestic homicide. At the same time, a subordinate discourse is also emergent in the coverage that young Muslim women's insistence on wearing the hijab (see Fatah, 2011) is a sign of their radicalization. Jasmin Zine's (2009) analysis of various flashpoints involving Muslim women in Canada provides a useful framework for analyzing the press coverage here. Zine posits the following logic as underpinning racist and discriminatory responses against Muslim women: death by culture, death of culture and disciplining culture. Death of culture speaks to the fear generated by the growing population of Muslims in Canada, a fear that was articulated most cogently in the reader driven response reported in the paper as part of its special series "Time to Lead", and also evident even in the paper's foregrounding of Muslim population figures in its series concerning a statistical profile of religious affiliation in Canada. These accounts seem to suggest a fear of being engulfed by Muslim masses and of the country being over-run by religious fanatics; this is also well documented by the large number of articles in our corpus that referenced matters of immigration. On the other hand, death by culture refers to the presumed victimized status of Muslim girls and women - their oppression as a result of being members of Muslim communities. Zine's notion of "disciplining culture" refers to both the invocation of a law and order response to stem what the media described as the growing tide of honour killings (Olwan, 2013), and the necessity of incarcerating young Muslim men in order to thwart terrorism.

\section{Cognitive Organizers and Repetitive Genealogies}

An interesting aspect of the coverage was the classification of the stories under particular capitalized headings. These headings were then followed by the actual title of the story. Discursively, these capitalized labels act as cognitive organizers, positioning the stories in a way that primes readers as to what to expect. For example, some of the stories concerning terror plots in Canada were prefaced by capitalized headings - "TERROR". At other times, this macro signifier was changed to "SECURITY". The links between terror and security were thus repetitively yoked. Another editorial, for instance, used the macro signifier

"TERRORISM/LONE WOLVES" underscoring the element of fear embodied in the figure of pathological single Muslim man on the loose but yet connected to an amorphous terrorist network.

The stories also recirculated previously published information, ostensibly to provide contextual information. Thus, in the news accounts about Omar Khadr, his family's connections with alQaeda were repeatedly raised. Similarly, in accounts concerning domestic terrorism, previous terror plots or terrorists were consistently mentioned, such as the Boston Marathon bombings (e.g. Freeze, 2011). There is a lineage established and it's a genealogy that helps to make sense of the newly posted information.

While the mention of such background information may be necessary, in the case of terrorism plots, such a systemic frame seals the interpretation of Muslims as problematic communities and Islam as an irrational phenomenon. To be sure, The Globe and Mail editorials consistently brought home the message that there are "good" Muslims out there and that Islam is not to blame (The Globe and Mail, 2010, October 5). But, this was often in an adhoc manner, and as a way to soothe any criticisms of bias that Muslim communities consistently level at the mainstream

Journal of Contemporary Issues in Education, 2016, 11(1), pp. 36-53.

ISSN 1718-4770 (C) 2016 University of Alberta/Centre for Global Citizenship Education and Research

http://ejournals.library.ualberta.ca/index.php/JCIE 
media. What stands out though is that coverage of other issues like violence against women, for instance, does not usually garner this same kind of systemic focus. Instead, in those cases, the news media tends to privilege singular interpretations; interpretations that construct a particular murder as more of an aberrant case and not part of a larger methodical pattern (Easteal, Judd, \& Holland, 2015).

\section{Concluding Remarks}

While the analysis presented here is by no means exhaustive and additional research is required to reach any substantive conclusions, we can surmise that the news media's representation of Muslim youth tends towards more negative and stereotypical portrayals that cohere around terrorism and crime, as well as clashes between tradition and modernity. Islam remains the central identifier in this nexus, connecting these youth in ways that surpass the commonplace and common sense notions of youth as a troublesome and rebellious category.

In the carceral gaze of the dominant society, the body of the Muslim youth is identifiable through the prism of soft and hard power; the hard power of the state in terms of incarceration, deportation and legal abandonment; and soft power in terms of "culture talk" (Mamdani, 2004). This is where the issues of youth alienation, and culture clash between tradition and modernity, assume a heightened legibility. Within the news media, and most especially in the press (which offers a more fixed interpretation and where information can be archived more readily), Muslim youth are both the enemies within and the enemies outside. They are barbarians in and of the land.

Journal of Contemporary Issues in Education, 2016, 11(1), pp.36-53. 


\section{References}

Some of the news articles listed below are not available online but can be found in print and on the database used for this paper.

Abu-Lughod, L. (2002). Do Muslim women really need saving? Anthropological reflections on cultural relativism and its Others. American Anthropologist, 104(3), 783-790. http://dx.doi.org/10.1525/aa.2002.104.3.783

Anderson, E. (2013, July 1). Surgeon Fahima Osman leaves her underdog status behind. The Globe and Mail. Available at http://www.theglobeandmail.com/news/national/surgeonfahima-osman-an-underdog-no-longer/article12913244/

Andreatti, D., Mahoney, J., \& White, P. (2013, July 30). Shooting spurs protests, grief; Police chief under pressure after an officer shoots and kills knife-wielding teen on streetcar. The Globe and Mail.

Bahdi, R. (2003). No exit: Racial profiling and Canada's war against terrorism. Osgoode Hall Law Journal, 41(2 \& 3), 293-316.

Baird, B. (2009). Morality and patriarchal white sovereignty, three stories of gang rape in Australia. International Feminist Journal of Politics, 11(3), 372-391. http://dx.doi.org/10.1080/14616740903017695

Bascaramurty, D. (2011, July 4). The gap between two solitudes; young Canadian Muslims say bridging the 'us and them' divide requires breaking down some harmful, outdated stereotypes. The Globe and Mail.

Bhattacharyya, G. (2008). Dangerous brown men, exploiting sex, violence and feminism in the War on Terror. London \& New York: Zed Books.

Blaze Carlson, K. (2013, July 31). Toronto witness recalls scene on streetcar before Sammy Yatim's death. The Globe and Mail. Available at http://www.theglobeandmail.com/news/toronto/toronto-witness-recalls-scene-onstreetcar-before-sammy-yatims-death/article13522919/

Blaze Carlson, K., \& Kauri, V. (2013, August 3). Caught between two worlds. The Globe and Mail. Available at http://www.theglobeandmail.com/news/toronto/caught-between-twoworlds/article13587522/?page=all

Boggs, C., \& Pollard, T. (2006). Hollywood and the spectacle of terrorism. New Political Science, 28(3), 335-351. http://dx.doi.org/10.1080/07393140600856151

Byng, M. D. (2010). Symbolically Muslim: Media, hijab, and the West. Critical Sociology, 36(1), 109-129. http://dx.doi.org/10.1177/0896920509347143

Chase, S., \& White, P. (2010, October 4). Be on lookout for radicalized youth, Toews says. The Globe and Mail. Available at http://www.pressreader.com/canada/the-globe-and-mail-bcedition/20101004/289416372325762

Dossa, S. (2008). Lethal Muslims: White-trashing Islam and the Arabs. Journal of Muslim Minority Affairs, 28(2), 225-236. http://dx.doi.org/10.1080/13602000802303169

Easteal, P. L., Judd, K., \& Holland, K. (2015). Enduring themes and silences in media portrayals of violence against women. Women's Studies International Forum, 48, 103-113. http://dx.doi.org/10.1016/j.wsif.2014.10.015

Fatah, N. (2011, July 6). The kids are not all right. The Globe and Mail. Available at http://www.pressreader.com/canada/the-globe-and-mail-metro-ontario-

Journal of Contemporary Issues in Education, 2016, 11(1), pp. 36-53.

ISSN 1718-4770 C 2016 University of Alberta/Centre for Global Citizenship Education and Research

http://ejournals.library.ualberta.ca/index.php/JCIE 
edition/20110706/284558764606994

Foucault, M. (2003). Society must be defended. Lectures at the Collège de France 1975-1976. (D. Macey, Trans.). New York: Picador.

Freeze, C. (2010, January 11). Terrorism/Toronto 18 trial. Suspect in Toronto bombing plot accused of seeking to cash in on chaos. The Globe and Mail. Available at http://www.theglobeandmail.com/news/national/toronto-bomb-plot-suspect-accused-ofseeking-to-cash-in-on-chaos/article1207521/

Freeze, C. (2011, September 1). Terror-wing inmates denounce 'savagery'; Bomb -plotters kept apart from general population because they could radicalize others, but programs for rehabilitation prove tricky. The Globe and Mail.

Freeze, C. (2013, February 2) Canadian extremists more likely homegrown: 'Secret' CSIS report. The Globe and Mail. Available at http://www.theglobeandmail.com/news/national/canadian-extremists-more-likelyhomegrown-secret-csis-report/article8149887/

Freeze, C., \& Friesen, J. (2013, September 30). Why the Canadian pipeline to al-Shabab has dried up. The Globe and Mail. Available at http://www.theglobeandmail.com/news/world/why-the-canadian-pipeline-to-al-shababhas-dried-up/article14620270/

Gee, M. (2013, August 2). With the sorrow, a search for answers in Sammy Yatim's slaying. The Globe and Mail. Available at http://www.theglobeandmail.com/news/toronto/withthe-sorrow-a-search-for-answers/article13587580/

Hage, G. (1998). White nation: Fantasies of white supremacy in a multicultural society. New York and Australia: Routledge and Pluto Press.

Hall, S. (Ed.). (2007). Representation, cultural representation and signifying practices. London: Sage in association with The Open University.

Hall, S., Critcher, C., Jefferson, T., Clarke, J., \& Roberts, B. (1978). Policing the crisis: Mugging, the State, law and order. London: MacMillan Press. http://dx.doi.org/10.1007/978-1-349-15881-2

Haque, E. (2010). Homegrown, Muslim and Other: Tolerance, secularism and the limits of multiculturalism. Social Identities, 16(1), 79-101. http://dx.doi.org/10.1080/13504630903465902

Harris, A., \& Roose, J. (2014). DIY citizenship amongst young Muslims: Experiences of the 'ordinary'. Journal of Youth Studies, 17(6), 794-813. http://dx.doi.org/10.1080/13676261.2013.844782

Helly, D. (2004). Are Muslims discriminated against in Canada since September 2001? Canadian Ethnic Studies, 36(1), 24-47.

Hirji, F. (2011). Through the looking glass: Muslim women on television - An analysis of 24, Lost, and Little Mosque on the Prairie. Global Media Journal - Canadian Edition, 4(2), $33-47$.

Hui, A., Freeze, C., \& Thanh Ha, T. (2013, April 3) Old classmate of two accused in Algerian plot became increasingly isolated, former co-worker says. The Globe and Mail. Available at http:/www.theglobeandmail.com/news/national/old-classmate-oftwo-accused-inalgeria-plot-became-increasingly-isolated-former-co-workersays/article10733295/

Jiwani, Y. (2004). Gendering terror: Representations of the orientalized body in Quebec's postSeptember 11 English-language press. Critique: Critical Middle Eastern Studies, 13(3),

Journal of Contemporary Issues in Education, 2016, 11(1), pp. 36-53. 
265-291. http://dx.doi.org/10.1080/1066992042000300657

Jiwani, Y. (2009). Helpless maidens and chivalrous knights: Afghan women in the Canadian press. University of Toronto Quarterly, 78(2), 728-744. http://dx.doi.org/10.3138/utq.78.2.728

Jiwani, Y. (2010). Soft power - policing the border through Canadian TV crime drama. In J. Klaehn (Ed.). The political economy of media and power (pp. 275-293). New York: Peter Lang.

Jiwani, Y. (2011). Trapped in the carceral net: Race, gender, and the 'War on Terror'. Global Media Journal - Canadian Edition, 4(2), 13-31.

Jiwani, Y. (2014). Posthumous rescue: The Shafia young Women as worthy victims. Girlhood Studies, 7(1), 27-45. http://dx.doi.org/10.3167/ghs.2014.070104

Karim, H. K. (2000). Islamic Peril. Montreal, Québec: Black Rose Books.

Kassam, S. (2011). Marketing an imagined Muslim woman: Muslim Girl magazine and the politics of race, gender and representation. Social Identities, 17(4), 543-564. http://dx.doi.org/10.1080/13504630.2011.587308

Khalema, N. E., \& Wannas-Jones, J. (2003). Under the prism of suspicion: Minority voices in Canada post-September 11. Journal of Muslim Minority Affairs, 23(1), 25-39. http://dx.doi.org/10.1080/13602000305928

Kitzinger, J. (2000). Media templates: Patterns of association and the (re)construction of meaning over time. Media, Culture \& Society, 22(1), 61-84. http://dx.doi.org/10.1177/016344300022001004

Magnet, S.A. (2012). When biometrics fail: Gender, race, and the technology of identity. Durham \& London: Duke University Press.

Mahoney, J., Andreatta, D., \& White, P. (2013, July 30). Toronto police chief responds to public outcry after fatal streetcar shooting. The Globe and Mail. Available at http://www.theglobeandmail.com/news/toronto/toronto-police-chief-to-speak-to-mediaabout-ttc-shooting-on-monday-morning/article13476777/

Maira, S. (2009). Missing: Youth, citizenship and empire after 9/11. Durham \& London: Duke University Press. http://dx.doi.org/10.1215/9780822392385

Makin, K. (2010, October 26). Canada's parole rules will benefit Khadr; Prisoner's celebrity status in his home country and the high level of support he's garnered also expected to help him. The Globe and Mail.

Mamdani, M. (2004). Good Muslim, bad Muslim: America, the Cold War and the roots of terror. New York: Pantheon.

Miller, J., \& Sack, C. (2010). The Toronto - 18 terror case: Trial by media? How newspaper opinion framed Canada's biggest terrorism case. International Journal of Diversity in Organizations, 10(1), 279-295.

Morey, P., \& Yaqin, A. (2011). Framing Muslims: Stereotyping and representation after 9/11. Cambridge \& Massachusetts: Harvard University Press. http://dx.doi.org/10.4159/harvard.9780674061149

Muscati, S.A. (2002). Arab/Muslim 'Otherness': The role of racial constructions in the Gulf War and the continuing crisis with Iraq. Journal of Muslim Minority Affairs, 22(1), 131-148. http://dx.doi.org/10.1080/13602000220124872

Odartey-Wellington, F. (2009). Racial profiling and moral panic: Operation Thread and the AlQaeda sleeper cell that never was. Global Media Journal - Canadian Edition, 2(2), 25-

Journal of Contemporary Issues in Education, 2016, 11(1), pp. 36-53.

ISSN 1718-4770 C 2016 University of Alberta/Centre for Global Citizenship Education and Research

http://ejournals.library.ualberta.ca/index.php/JCIE 
40.

Odartey-Wellington, F. (2011). Erasing race in the Canadian media: The Case of Suaad Hagi Mohamud. Canadian Journal of Communication, 36(3), 395-414.

Olwan, D. M. (2013). Gendered violence, cultural Otherness, and honour crimes in Canadian national logics. Canadian Journal of Sociology, 38(4), 533-555.

Pugliese, J. (2009). Compulsory visibility and the infralegality of racial phantasmata. Social Semiotics, 19(1), 9-30. http://dx.doi.org/10.1080/10350330802632758

Razack, S. (2008). Casting out: The eviction of Muslims from Western law and politics. Toronto: University of Toronto Press.

Richardson, J. E. (2004). (Mis)Representing Islam: The racism and rhetoric of British broadsheet newspapers. Amsterdam/Philadelphia: John Benjamins Publishing. http://dx.doi.org/10.1075/dapsac.9

Said, E. W. (1981). Covering Islam: How the media and experts determine how we see the rest of the world. New York: Pantheon Books.

Said, E. W. (1978). Orientalism. New York: Vintage Books.

Sampert, S. (2006). Asking for it? The use of blame in the depiction of sexual assault crime in local English Canadian newspapers. Annual Meeting of the Canadian Political Science Association. York University.

Sensoy, O., \& Marshall, E. (2010). Missionary girl power: Saving the 'Third World' one girl at a time. Gender and Education, 22(3), 295-311.

http://dx.doi.org/10.1080/09540250903289451

Shaheen, J. G. (2001). Reel bad Arabs: How Hollywood vilifies a people. New York: Olive Branch Press.

Shephard, M. (2008). Guantanamo's child. Mississauga, Ontario: John Wiley \& Sons.

Smolash, W.N. (2009). Mark of Cain(ada): Racialized security discourse in Canada's national newspapers. University of Toronto Quarterly, 78(2), 745-763. http://dx.doi.org/10.3138/utq.78.2.745

Stenvall, M. (2003). An actor or an undefined threat? The role of 'terrorist' in the discourse of international news agencies. Journal of Language and Politics, 2(2), 361-404. http://dx.doi.org/10.1075/jlp.2.2.10ste

Steuter, E., \& Wills, D. (2009). Discourses of dehumanization: Enemy construction and Canadian media complicity in the framing of the War on Terror. Global Media Journal Canadian Edition, 2(2), 7-24.

The Globe and Mail. (2010, October 5). Tipping off is a duty. Editorial.

The Globe and Mail. (2010, November 1) Strange spectacle of Guantanamo justice. Editorial. Available at http://www.pressreader.com/canada/the-globe-and-mail-metro-ontarioedition/20101101/285804304856744

The Guardian. (2015, November 23). Canada to turn away single men as part of Syrian refugee resettlement plan. Available at http://www.theguardian.com/world/2015/nov/23/canadasyrian-refugee-resettlement-plan-no-single-men

van Dijk, T. A. (1993). Elite discourse and racism. Newbury Park, CA: Sage Publications. http://dx.doi.org/10.4135/9781483326184

Wente, M. (2010, August 31). A hate filled product of poverty or a ball-playing doctor? The Globe and Mail.

Wente, M. (2013, July 4). There'll always be weirdos in the basement. The Globe and Mail.

Journal of Contemporary Issues in Education, 2016, 11(1), pp. 36-53.

ISSN 1718-4770 (C) 2016 University of Alberta/Centre for Global Citizenship Education and Research

http://ejournals.library.ualberta.ca/index.php/JCIE 
Available at http://www.theglobeandmail.com/opinion/therell-always-be-weirdos-in-thebasement/article12960420/

Williamson, J. (Ed.). (2012). Omar Khadr: Oh Canada. Montreal: McGill-Queen's University Press.

Wingrove, J. (2012, November 20). For Alberta's 'child of the snow', time is running out. The Globe and Mail.

Zine, J. (2002). Muslim women and the politics of representation. American Journal of Islamic Social Sciences, 19(4), 1-23.

Zine, J. (2009). Unsettling the nation: Gender, race and Muslim cultural politics in Canada.

Studies in Ethnicity and Nationalism, 9(1), 146-193. http://dx.doi.org/10.1111/j.17549469.2009.01036.x 